\title{
The Complexity of Wholesale Distribution Channels in Japan
}

\author{
David Flath and Tastuhiko Nariu
}

Working Paper No. 60

\author{
Professor David Flath \\ Department of Economics \\ North Carolina State University \\ Raleigh, North Carolina \\ Professor Tatsuhiko Nariu \\ Associate Professor of Marketing \\ School of Business Administration \\ Nanzan University, Nagoya, Japan
}

Working Paper Series

Center on Japanese Economy and Business

Graduate School of Business

Columbia University

November 1991 
THE COMPLEXITY OF WHOLESALE DISTRIBUTION CHANNELS IN JAPAN

Tatsuhiko NARIU and David FLATH*

September 1991

\section{Abstract}

A measure of number of steps in the wholesale distribution chain is proposed and calculated for Japan, the U.S., and Germany and for different kinds of business within Japan and within the U.S.. Economic factors that influence the number of wholesale steps in the distribution channel are examined in relation to these data.

*respectively, Associate Professor of Marketing, School of Business Administration, Nanzan University, 18 Yamazato-cho, Showa-ku, Nagoya 466 JAPAN, tel. (052)832-3111, ext.438. FAX: 81-052-8336986; and Professor, Department of Economics, NCSU, Raleigh, NC 27695-8110, (919)515-3884 . FAX: (919)515-3787. 
THE COMPLEXITY OF WHOLESALE DISTRIBUTION CHANNELS IN JAPAN

The Japanese distribution system is frequently characterized as having long and convoluted marketing channels that include secondary and even tertiary wholesalers, ${ }^{2}$ but few papers have treated this subject at length. This one does. We construct new estimates of the number of steps in the wholesale distribution channels of Japan and the U.S. both nationally and by kind of business, using census data. Based on these estimates, the marketing channels of Japan do indeed have more steps on average than do those of analogous products in the U.S., just as many have claimed.

Besides documenting the complexity of wholesale distribution channels in Japan we aim also to understand the reasons. Our estimates show that in general, products having relatively long wholesale marketing channels in Japan also have relatively long wholesale channels in the United States. But we find that products having relatively many wholesale steps in both countries, for instance fresh fish, account for a larger share of sales in Japan than in the U.S.. That is, the pattern of trade in Japan favors products that have long and complex wholesale marketing channels. This is one reason why the wholesale sector of Japan is more complex than that of the U.S. if we compare the two countries' wholesale marketing channels gobally rather than product by

${ }^{1} A$ rare exception to this is Ejiri (1980) who claims that distribution channels in Japan are short and direct and not complex as is usually claimed. Most surveys of the Japanese marketing system include multiplicity of wholesale steps among its salient features along with the ubiquity of stores, and prevalence of vertical restraints. See for instance Yoshino (1971), Tamura (1986), or Keizai kikakucho (1986). 
product, but it is clearly not the only reason.

We use the technique of statistical regression to explore hypothesese about the Japan-U.S. differences in number of wholesale steps by kind of business. Many have claimed that Japan's ubiquity of small stores is an important factor behind the complexity of wholesale distribution channels (Ratcliffe (1975), Tsurumi (1982), Maruyama, et al (1991)). We offer some evidence in support of this thesis. We show that for kinds of business in Japan for which retail stores are particularly numerous compared to the U.S., wholesale channels have relatively more steps in Japan than in the U.S.. However, not only consumer goods but also industrial goods have longer wholesale channels in Japan than in the U.S. according to our estimates. Perhaps fragmentation of industrial demanders has a similar influence on the Japanese marketing system as does the ubiquity of retail stores.

Not all wholesale marketing channels in Japan have more steps than do the corresponding channels in the U.S.. Goods with relatively few steps in Japan compared to the U.S. include motor vehicles and electric appliances. We offer the thesis that coordination of channel members through so-called distribution keiretsu favors less complex wholesale channels in Japan compared to the U.S.. On balance the forces favoring longer channels in Japan than elsewhere are apparently the stronger ones for most products. 


\section{Measuring the Number of Wholesale "Steps".}

\subsection{Method of measurement.}

Sales from wholesalers to wholesalers is one index of the number of wholesale steps. Ito and Maruyama (forthcoming), Table 2-4, report that percentage of merchant wholesalers' sales that are to other wholesalers is $41.9 \%$ for Japan, $24.8 \%$ for the United States and $16.2 \%$ for Germany. This, as they note, confirms the many commentaries to the effect that marketing channels in Japan are long and complicated and frequently include secondary and even tertiary wholesalers. In this section we propose a more exact measure of the length of marketing channels, an estimate of the average actual number of wholesale steps. ${ }^{2}$

Imagine that the typical manufacturer sells to a primary wholesaler at price $P_{0}$ and that the wholesaler sells to a secondary wholesaler at price $P_{1}$ and so on until the last wholesaler in the chain sells (to a retailer say) at price $\mathrm{P}_{\mathrm{N}}$. Here the number of steps is $N$. Suppose that the average wholesale markup $P_{j+1} / P_{j}$ is the same for all $\mathrm{j}=0, \ldots, \mathrm{N}-1$. Now the total markup in the chain is

$$
\text { (1) } \frac{P_{N}}{P_{0}}=\frac{P_{1}}{P_{0}} \cdot \frac{P_{2}}{P_{1}} \cdot \ldots \cdot \frac{P_{N}}{P_{N-1}}=\left(\frac{P_{j+1}}{P_{j}}\right)^{N} \text {. }
$$

Thus from estimates of the total markup in the chain and the average markup one can recover an estimate of the number of steps. Now the average wholesale markup is approximately the reciprocal of

${ }^{2}$ Our measure of number of steps was first developed in Tatsuhiko Nariu's 1989 Ph.D. dissertation at NCSU "Economic Analysis of Marketing and Distribution", pp. 40-42. 
one minus the gross profit margin rate of wholesalers:

(2) $\frac{P_{j}}{P_{j-1}} \approx(1-" \text { gross profit margin rate" })^{-1}$,

where

$$
\text { (3) } \underset{\operatorname{margin}}{\operatorname{mate}} \approx \frac{\left(P_{N}-P_{0}\right) q}{\sum_{i=1}^{N} P_{i} q}=\frac{1}{\sum_{i=1}^{N} P_{i}}\left(\frac{\left(P_{N}-P_{N-1}\right) P_{N}}{P_{N}}+\ldots+\frac{\left.P_{1}-P_{0}\right) P_{1}}{P_{1}}\right)=\frac{P_{j}-P_{j-1}}{P_{j}}
$$

The total markup in the chain can be inferred from the gross profit margin rate and the fraction of wholesalers' sales that are not to other wholesalers:

$$
\text { (4) } \frac{P_{N}}{P_{0}}=\frac{\frac{P_{N} q}{\sum_{i=1}^{N} P_{i} q}}{\frac{P_{N} q}{\sum_{i=1}^{N} P_{i} q}-\frac{\left(P_{N}-P_{0}\right) q}{\sum_{i=1}^{N} P_{i} q}} \approx \frac{\begin{array}{c}
\text { Fraction of } \\
\text { wholesalesales } \\
\text { not to other } \\
\text { wholesalers }
\end{array}}{\begin{array}{c}
\text { Fraction of Gross } \\
\text { whosale sales_profit } \\
\text { notoother margin } \\
\text { wholesalers rate }
\end{array}}
$$

The variable NS, which is our proxy for the number of wholesale steps, is the natural logarithm of the total markup calculated as detailed above, divided by the natural logarithm of the average markup:

$$
\text { (5) } N S=\frac{\ln \left(P_{N} / P_{0}\right)}{\ln \left(P_{j} / P_{j-1}\right)}
$$


1.2. Number of wholesale steps in Japan compared with the U.S. and Germany.

Gross profit margin rate of wholesalers is reported in Ito and Maruyama (forthcoming) Table 3-4, and for 1986 is $11.2 \%$ for Japan, 19.4\% for the U.S. and $12.6 \%$ for Germany. The total markup constructed from Ito and Maruyama, Table 3-4, and Table 2-4, is 1.239 for Japan, 1.348 for the U.S., and 1.171 for Germany. The resulting estimates of the number of steps NS are 1.798 for Japan, 1.384 for the U.S., and 1.216 for Germany. This exercize does therefore confirm that wholesale distribution channels in Japan are rather more complex than is true of other developed countries, just as many commentators have alleged. All the figures just described are included in Table 1.

1.3. Number of wholesale steps by kind of business in Japan and the U.S.

To analyze the complexity of wholesale marketing channels in Japan more completely we have attempted to match kinds of wholesale business between Japan and the U.S. ${ }^{3}$ and compute number of wholesale steps for each. The results of this exercize are

${ }^{3}$ Our matching of wholesale businesses in Japan and the U.S. can be compared with that of Nishimura and Tsubouchi (1990), pp. 118-121. They have grouped the businesses into 15 broad categories, which is enough for their purpose but not ours. Their purpose is to compare the gross margins in the two countries, to deflect criticisms that the Japanese distribution sector adds greatly to the cost of supplying goods compared to that of the U.S. . 
reported in Table $2 .^{4}$

In Table 2 we report estimates of number of wholesale steps for each of 40 different kinds of business in Japan (in 1986) and for 44 different kinds of business in the U.S. (in 1982). We begin our analysis of these data with four observations. First, the simple average of number of steps across kinds of business is 1.48 for Japan compared to 1.36 for the U.S., which is far closer than the national estimates described in the previous section. Recall that the estimated numbers of steps based on aggegates for all wholesalers are 1.80 for Japan and 1.38 for the U.S.. One cause of these contrasting results is that products that have relatively long marketing channels in both Japan and the U.S. account for a larger fraction of final sales in Japan. For instance, the greatest number of wholesale steps both in Japan and in the U.S. was for fresh fish and seafood: 2.27 steps in the U.S. and 2.56 in Japan. Yet sales of fresh fish in Japan far exceed those in the U.S. .

Second, though the Japan-U.S. difference in number of steps is small it is pervasive. The greater number of wholesale steps in

${ }^{4}$ In computing gross profit margin rates for each kind of business in Japan, profit-to-sales ratios and CoGS-to-sales ratios for each class of wholesaler based on random samples as reported in MITI's "jittai chosa", were aggregated in proportion to the sales of each class as reported for the universe of each in the same volume. The three classes are primary, secondary, and tertiary wholesalers. We employed an analagous aggregation procedure in constructing the total markups in each Japanese wholesale chain.

For the US, gross profit margin rates are reported for broad kinds of business directly in the commerce Department's "Miscellaneous Subjects". We had to employ the same estimated gross profit margin rate for each kind of business included in the same broad category. 
Japan compared to the U.S. is not limited to specific products. Motor vehicles, furniture, hardware, electric household appliances, piece goods, dairy products, confectionery and petroleum are all estimated to have longer channels in the U.S. than in Japan. But except for motor vehicles, petroleum and hardware these product categories are not closely matched between the two countries and should only be compared cautiously. For instance dairy products are reported separately for the U.S. but included with miscellaneous food products in Japan. An analagous statement is true of piece goods. Also bakery products are included with confectionery in Japan but not in the U.S.. Most products that can be reliably compared between the two countreis seem to have longer wholesale channels in Japan. But motor vehicles, hardware and petroleum are notable exceptions; they all have shorter channels in Japan than in the U.S..

Third, there is a clear tendency for products that have long marketing channels in one country to also have long channels in the other. The simple correlation between estimated number of steps in Japan and in the U.S. is 0.504 . We already mentioned that fresh fish has the greatest number of steps in both countries. More generally, the ratio of number of steps in Japan to those in the U.S. by kind of business has mean=1.08 and standard deviation= 0.17, and t-statistic for mean=1 of 2.75. That is, in a statistical sense the typical pattern in the data is for there to be more steps in Japan than in the analogous marketing channel in the U.S. but for the difference to be a slight one. 
Finally, the kinds of business that exhibit the greatest difference in number of steps between Japan and the U.S. (besides motor vehicles which as already mentioned has fewer steps in Japan) are: china and glassware, curtains and draperies, lumber, building materials, paper, and canned goods, all of which have more steps in Japan. This list includes some industrial products as well as household products. 5

\section{The Structure of Distribution Channels.}

In this section we take up two questions. First, what accounts for the variation in numbers of wholesale steps across kinds of business. And, second, based on this analysis, what might account for the apparently longer wholesale marketing channels in Japan than elsewhere.

\subsection{Factors common to Japan and the U.S.}

The "number of wholesale steps" refers to the number of separate title-holding intermediaries interposed between a manufacturer and retailers or industrial demanders. Even in a direct marketing channel, one having zero wholesale steps, goods are sometimes shipped to intermediate collection points to economize on transport costs. This is because there often are cost

${ }^{5}$ The percentages of final sales of these goods by wholesalers (i.e., percentage of sales not to other wholesalers) that are to retailers are: chinaware and glassware (72\%), curtains and drapes $(75 \%)$, lumber $(35 \%)$, building materials (26\%), nonferrous metals (6\%), hardware (47\%), paper (21\%) canned goods ( $84 \%)$, and chemicals (14\%). These figures are based on shogyo tokei hyo 1985, ryutsu keiro betsu tokei hen, Table 1 . 
savings from consolidating shipments. The post office exploits the same principle in routing mail. Bucklin (1965), in an early piece that is still worthy of attention, argues that title-holding intermediaries emerge only if wharehouse inventories are speculative rather than merely logistical as in the post office example. Speculative inventories are any which are not yet promised to final customers and are therefore of uncertain market value. Merchant wholesalers are specialists at economizing on the risk and uncertainty attached to the holding of speculative inventories.

Bucklin convincingly argues that wholesale steps proliferate where speculative inventories are valued. If customers have relatively high storage costs, they will pay more for the added convenience of next-door shopping because it enables them to replenish stocks frequently and keep their own inventories low. But in order to provide this service marketers must maintain speculative inventories close to the customers. Fresh fish and fresh produce are costly to store and must be dispatched quickly to avert spoilage. The large number of wholesale steps for these in both Japan and the U.S. reflect the necessity of maintaining speculative inventories if customers are to be supplied on demand.

As Bucklin further points out, distribution through exclusive outlets or closely coordinated channels enables a manufacturer to more perfectly anticipate customers' desires and reduce or avoid speculative inventories. These channels will therefore have fewer wholesale steps. Here one thinks of motor vehicles, which has few 
wholesale steps in both Japan and the U.S..

\subsection{Factors Specific to Japan}

The ubiquity of retail stores in Japan is often identified as one reason why the number of wholesale steps is greater in Japan than elsewhere. If we follow Bucklin's reasoning as sketched in the previous section, it may be more correct to say that Japan's ubiquity of stores and multiplicity of wholesale steps have a common basis--economies on household storage. Both are ways of assuring that speculative inventories are maintained in close proximity to final demanders and enabling the demanders to restock frequently.

A previous paper, Flath (1990), argues that Japan's ubiquity of retail outlets rests upon final demanders' high costs of storage relative to the distribution sector's costs of storage and upon the short geographic distance between point of production and point of consumption: Japan's proliferation of retail outlets both has greater economic value and lower costs in Japan than it would elsewhere. It is logical to suppose that the same forces give rise to speculative inventories and enlarge the number of wholesale steps in the Japanese marketing channels.

We also can gain insight into Japan's wholesale system by considering the few products that actually have shorter marketing channels in Japan than in the U.S. including motor vehicles and electric appliances according to our estimates. These are products that require special promotion, service and attention to quality 
and that therefore engender free-riding problems along the distribution channel. For these products and others manufacturers and wholesalers in Japan coordinate their actions in ways that promote their common interests. As already mentioned, coordination among channel members reduces the uncertainty attached to speculative inventories and narrows the scope for profitable actions by title holding intermediaries. There are reasons to believe that such coordination is more elusive outside of Japan for it is firmly rooted in long reliance on implicit contracts, a distinctive feature of the Japanese way of conducting business. Perhaps because of this, marketing channels in Japan with a high level of coordination, that is where so-called distribution keiretsu are prevalent, tend to have fewer wholesale steps than do analogous marketing channels in the U.S.. This includes motor vehicles, electric appliances, and other goods besides.

\section{Statistical Analysis}

We can validate some of the reasoning sketched in the previous section by regression analysis of the estimated number of wholesale steps for different kinds of business in Japan. We regress number of wholesale steps in Japan on the estimated number of steps in analogous kinds of business in the U.S., numbers of retail stores per household selling products corresponding to the wholesale kinds of business in Japan relative to the U.S., ${ }^{6}$ and fraction of the

${ }^{6}$ From Flath (1990), Table 3b, p. 381, stores per household in Japan relative to the U.S. are as follows: Hardware and garden supplies 1.371, General merchandise 0.179 , Food 5.266, Motor 
Japanese wholesalers in each kind of business receiving assistance from upstream firms. The coefficient estimates are reported in Table 3 .

The first result is that estimated number of wholesale steps in the U.S. is a statistically significant predictor of the number of wholesale steps in Japan. This demonstates that there are significant economic factors influencing the length of marketing channels that are common to both countries.

The second result is that kinds of business having a proportionately greater density of retail outlets in Japan than in the U.S. also have significantly more wholesale steps in Japan than in the U.S.. Japan's ubiquity of retail stores and complex wholesale marketing channels are indeed linked to one another statistically. Perhaps a similar force is operating on marketing channels for industrial goods as well given the large number of very small manufacturing firms in Japan, the demanders of industrial goods, but our data do not permit us to test this.

A third result is that where coordination among channel members is present in Japan as indicated by a high incidence of wholesalers reporting assistance from upstream firms, the number of wholesale steps is significantly less, controlling for factors common to both Japan and the U.S.. We interpret this as support for the claim that the Japanese institutions for coordinating and managing marketing channels generally favor less complex wholesale

vehicles 0.832, Gasoline stations 0.858, Apparel 3.256, Furniture and fixtures 3.511, Drugs and toiletries 3.694 , and Liquor 5.796. 
channels with fewer steps than in the analagous American marketing channels, the opposite of what is observed for most products. Apparently the Japanese facility at coordinating marketing channels is more than offset by the other factors bearing on the number of wholesale steps.

\section{Conclusion}

Academic Japan specialists in the fields of economics and marketing have only recently begun to propose serious explanations for the salient features of Japan's distribution system and to test these explanations. This "new wave" in the study of Japan's distribution system is now threatening to eclipse the earlier depictions of an anachronistic, backwards and grossly inefficent marketing system. Where earlier studies purported merely to describe or document the ways in which the Japanese marketing system is unique, the newer studies attempt also to understand the reasons for these differences. The emerging view is that the apparent complexity of marketing channels in Japan masks an underlying logic.

The long marketing channels and multiple wholesale steps which are commonly encountered in the Japanese market follow a systematic pattern. Products such as fresh fish that have particularly complex marketing channels in Japan have similarly complex marketing channels in the U.S.. Nevertheless the typical wholesale marketing channel in Japan has more steps than does its U.S. analogue. We have demonstrated that the multiplicity of wholesale 
steps for consumer products in Japan is statistically linked to the ubiquity of retail stores selling the same products, which suggests that Japan's ubiquity of stores and compexity of wholesaling have a common basis. We know that marketing channels for many industrial products in Japan end in sales to small manufacturing subcontractors, but the lack of suitable data prevented us from establishing a statistical link between that and the length of marketing channels for industrial products. This remains a topic for future investigation. Finally, we have shown that marketing channels that are coodinated through so-called distribution keiretsu tend to have fewer wholesale steps.

It may be worthwhile to suggest some practical lessons to be drawn from this inquiry though in doing so we risk exaggerating our contribution to the practice of marketing. The first lesson is that marketing channels vary across products in ways that are common to both Japan and the U.S.. Knowledge of the product and the problems encountered in marketing it in the U.S. may be more helpful to Americans trying to do business in Japan than any knowledge of a more general nature about the peculiar aspects of the Japanese distribution system.

A second lesson is that the least complex wholesale marketing channels in Japan need not be the most open to imports. Close coordination of channel members through vertical restraints and so on is a force towards fewer wholesale steps but arguably also implies less openness.

A third and final lesson is that marketing channels in Japan 
are relatively complex where there is an economic advantage to their being so. There are no easy riches to be had by sidestepping or shortcutting the existing wholesale channels in selling to the Japanese. Passing goods through the existing channels with their multiplicity of wholesale steps may well be the least cost way of marketing goods to consumers willing to pay a higher premium than Americans for the convenience of next-door shopping or businesses willing to pay a higher premium than American ones for rapid delivery. 


\section{BIBLIOGRAPHY}

Bucklin, Louis P. (1965). "Postponement, Speculation, and the Structure of Distribution Channels," Journal of marketing Research, v. 2, pp. 26-31.

Ejiri, Hiroshi (1980). "Waga kuni no ryutsu keiro wa honto ni nagai ka" (are distribution channels really longer in Japan?) shohi to ryutsu, vol. 4, no. 3, pp. 60-70, and vol. 4, no. 4, pp. 72-79.

Flath, David (1990). "Why Are There So Many Retail stores in Japan?" Japan and the World Economy, 2, 365-386.

Ito, Takatoshi and Masayoshi Maruyama (forthcoming), "Is the Japanese Distribution system Really Inefficient?", in Paul Krugman, ed., The United States and Japan : Trade and Investment, University of Chicago Press, NBER.

Keizai kikaku cho bukka kyoku bukka seisaku ka (Economic Planning Agency, Price Level Division) (1986). Yunyuhin no ryutsu oyobi shokanko (Commercial practices and the marketing of imports). Tokyo.

Maruyama, Masayoshi; Kyohei Sakai; Yoko Togawa; Nobuo Sakamoto; Michiko Yamashita ; Masaharu Arakawa; and Hiroyuki Ijo (1991). "Nihon no ryutsu shisutemu: riron to jissho" (the distribuiton system of Japan: theory and empirics) keizai bunseki, no. 123 (May).

Nariu, Tastsuhiko. (1989) "Economic Analysis of Marketing and Distribution," Ph.D. dissertation in Economics, NCSU.

Nishimura, Kiyohiko and Tsubouchi, Hiroshi (1990). "gyoju, hinmoku betsu ryutsu majin ritsu sankei: nichi-bei hikaku" (U.S.Japan comparison of distribution margin rates, by product and by industry) keizaigaku ronso, vo. 56, no. 3. (October), pp. 111138 .

Ratcliffe, C. T. (1975). "Approaches to Distribution in Japan," in I. Frank, ed., The Japanese Economy in International Perspective. Baltimore: The Johns Hopkins University Press, Ch. 4, pp. 101-133.

Tamura, Masanori (1986). Nihon gata ryutsu shisutemu (the Japanese distribution system), Tokyo: Chikura shobo.

Tsurumi, Y. (1982) "Managing Consumer and Industrial Marketing Systems in Japan," Sloan Management Review 24, 41-49.

Yoshino, Michael Y. (1971). The Japanese Marketing system: Adaptations and Innovations. Cambridge, MA: The MIT Press. 
DATA SOURCES

For the United States:

Gross margins of merchant wholesalers by kind of business are from:

U.S. Dept. of Commerce, Bureau of the Census, 1982 Census of Wholesale Trade, Industry Series: Measures of Value Produced, Capital Expenditures, Depreciable Assets, and Operating Expenses, Table 2 .

Fractions of merchant wholesalers' sales that are to other wholesalers, and fractions of wholesalers' final sales that are to retailers, by kind of business are from:

U.S. Dept. of Commerce, Bureau of the Census, 1982 Census of Wholesale Trade, Industry Series: Miscellaneous Subjects, Table 1.

For Japan:

Sales (shohin hanbai kaku) and Gross margin (sorieki - shohin hanbai kaku igai no shunyu kaku (gross profit less profits not due to wholesale activity)) by kind of business for primary, secondary and tertiary wholesalers separately are from the "jittai chosa":

Small and Medium Enterprise Agency, Research and Statistics Department, Minister's Secretariat, Ministry of International Trade and Industry, Report on 5 th Basic Survey of Commercial structure and Activity (as of October 1 1986), Report of Wholesale Trade, Table 4 .

To compute overall gross margins by kind of business, the gross margins of primary, seondary and tertiary wholesalers are weighted by sales of each respectively from:

Ibid, Table 24

... which is based on a survey with rather broader coverage than that of Table 4 .

Fractions of wholesalers receving asistance from upstream firms by kind of wholesale business for primary, secondary and tertiary wholesalers (ta kigyo ni yoru keiretsuka) are from:

Ibid, Table 54 .

...again weighted by sales from 
Ibid, Table 24 .

Numbers of stores per household in Japan compared to the U.S. are taken from Flath (1990), Table 3b, p. 381. 
Table 1. Number of wholesale steps in Japan, the US, and $W$. Germany

\begin{tabular}{|l|l|l|l|l|l|}
\hline & Year & $\begin{array}{l}\text { Gross } \\
\text { margin } \\
\text { rate }\end{array}$ & $\begin{array}{l}\text { Fraction of } \\
\text { wholsesale } \\
\text { sales not } \\
\text { to other } \\
\text { wholesalers }\end{array}$ & $\begin{array}{l}\text { Total } \\
\text { markup }\end{array}$ & $\begin{array}{l}\text { Estimated } \\
\text { average } \\
\text { number of } \\
\text { wholesale } \\
\text { steps }\end{array}$ \\
\hline \hline JAPAN & 1985 & .112 & .581 & 1.239 & 1.80 \\
\hline $\begin{array}{l}\text { United } \\
\text { States }\end{array}$ & 1985 & .194 & .752 & 1.348 & 1.38 \\
\hline $\begin{array}{l}\text { W. } \\
\text { Germany }\end{array}$ & 1986 & .126 & .638 & 1.171 & 1.22 \\
\hline
\end{tabular}

Sources. Gross margin rate and fraction of wholoesale sales not to other wholesalers from Ito and Maruyama (forthcoming), Tables, 2-4 and 3-4. Total markup and estimated average number of steps computed from the other items as described in the text. 
Table 2a. Estimated number of wholesale steps Japan and the U.S. by kind of wholesale business--durables.

\begin{tabular}{|c|c|c|c|c|c|}
\hline \multicolumn{3}{|c|}{ UNITED STATES } & \multicolumn{3}{|l|}{ JAPAN } \\
\hline sic & $\begin{array}{l}\text { kind of } \\
\text { business }\end{array}$ & NS & NS & kind of business & sic \\
\hline 50 & Durables & 1.27 & & & \\
\hline 5012 & Motor vehicles & 1.87 & 1.14 & Motor vehicles & 5042 \\
\hline 5013 & $\begin{array}{l}\text { Automotive } \\
\text { parts and } \\
\text { supplies }\end{array}$ & 1.59 & 1.51 & $\begin{array}{l}\text { Motor vehicle } \\
\text { parts and } \\
\text { accessories }\end{array}$ & 5043 \\
\hline 5021 & Furniture & 1.61 & 1.29 & $\begin{array}{l}\text { Furniture and } \\
\text { fixtures }\end{array}$ & 5151 \\
\hline 50231 & $\begin{array}{l}\text { China, } \\
\text { glassware, and } \\
\text { crockery }\end{array}$ & 1.04 & 1.41 & $\begin{array}{l}\text { Chinaware and } \\
\text { glassware }\end{array}$ & 5155 \\
\hline 50232 & $\begin{array}{l}\text { Linens, } \\
\text { domestics, } \\
\text { curtains, and } \\
\text { draperies }\end{array}$ & 1.11 & 1.48 & $\begin{array}{l}\text { Textiles, } \\
\text { interior } \\
\text { decoration }\end{array}$ & 5154 \\
\hline $\begin{array}{l}50233 \\
50239\end{array}$ & $\begin{array}{l}\text { Floor coverings } \\
\text { and other home } \\
\text { furnishings }\end{array}$ & 1.26 & 1.48 & $\begin{array}{l}\text { Miscellaneous } \\
\text { home furnishings }\end{array}$ & 5159 \\
\hline 5031 & $\begin{array}{l}\text { Lumber, } \\
\text { plywood, and } \\
\text { millwork }\end{array}$ & 1.24 & 1.68 & $\begin{array}{l}\text { Lumber and } \\
\text { bamboo }\end{array}$ & 5051 \\
\hline 50391 & $\begin{array}{l}\text { Brick, stone, } \\
\text { sand, tile, } \\
\text { and cement }\end{array}$ & 1.14 & 1.68 & Cement & 5052 \\
\hline 50392 & $\begin{array}{l}\text { Flat glass, and } \\
\text { other } \\
\text { construction } \\
\text { materials }\end{array}$ & 1.32 & 1.58 & Sheet glass & 5053 \\
\hline $\begin{array}{l}50393 \\
50399\end{array}$ & $\begin{array}{l}\text { Construction } \\
\text { materials } \\
\text { n.e.c. }\end{array}$ & 1.10 & 1.68 & $\begin{array}{l}\text { Miscellaneous } \\
\text { building } \\
\text { materials }\end{array}$ & 5059 \\
\hline $\begin{array}{l}5041 \\
5042\end{array}$ & $\begin{array}{l}\text { Sporting and } \\
\text { recreational } \\
\text { goods, and toys } \\
\text { and hobby goods }\end{array}$ & 1.27 & n.a. & $\begin{array}{l}\text { Sporting goods, } \\
\text { recreational } \\
\text { goods and toys }\end{array}$ & 5195 \\
\hline
\end{tabular}




\begin{tabular}{|c|c|c|c|c|c|}
\hline \multirow{2}{*}{$\begin{array}{l}\text { UNITED } \\
\text { sic }\end{array}$} & \multicolumn{2}{|l|}{ STATES } & \multicolumn{3}{|l|}{ JAPAN } \\
\hline & $\begin{array}{l}\text { kind of } \\
\text { business }\end{array}$ & NS & NS & kind of business & sic \\
\hline 5043 & $\begin{array}{l}\text { Photographic } \\
\text { equipment and } \\
\text { supplies }\end{array}$ & 1.48 & 1.33 & $\begin{array}{l}\text { Precision } \\
\text { instruments } \\
\text { including camera } \\
\text { equipment }\end{array}$ & 5045 \\
\hline 50511 & Ferrous metals & 1.51 & 1.72 & Iron and steel & 5035 \\
\hline 50512 & $\begin{array}{l}\text { Nonferrous } \\
\text { metals }\end{array}$ & 1.25 & 1.51 & $\begin{array}{l}\text { Nonferrous } \\
\text { metals }\end{array}$ & 5036 \\
\hline 50521 & $\mathrm{Coal}$ & 1.14 & 1.51 & Coal & 5031 \\
\hline $\begin{array}{l}5063 \\
5065\end{array}$ & $\begin{array}{l}\text { Electrical } \\
\text { goods other } \\
\text { than household } \\
\text { appliances }\end{array}$ & 1.15 & 1.25 & $\begin{array}{l}\text { Electrical } \\
\text { machinery, } \\
\text { apparatus and } \\
\text { supplies ex. } \\
\text { household } \\
\text { appliances }\end{array}$ & 5047 \\
\hline 5064 & $\begin{array}{l}\text { Electric } \\
\text { household } \\
\text { appliances, TV } \\
\text { and radio sets }\end{array}$ & 1.56 & 1.25 & $\begin{array}{l}\text { Electrical } \\
\text { household } \\
\text { appliances }\end{array}$ & 5046 \\
\hline 5072 & Hardware & 1.21 & 1.16 & Hardware & 5192 \\
\hline $\begin{array}{l}508 \\
\text { exc. } \\
50863 \\
\& \\
5088\end{array}$ & $\begin{array}{l}\text { Machinery and } \\
\text { equipment, } \\
\text { n.e.c. }\end{array}$ & 1.15 & 1.36 & $\begin{array}{l}\text { General } \\
\text { machinery and } \\
\text { equipment }\end{array}$ & 5041 \\
\hline 50863 & $\begin{array}{l}\text { Surgical, } \\
\text { medical and } \\
\text { hospital } \\
\text { supplies }\end{array}$ & 1.06 & 1.16 & Surgical goods & 5142 \\
\hline 5088 & $\begin{array}{l}\text { Transportation } \\
\text { equipment and } \\
\text { supplies except } \\
\text { motor vehicles } \\
\text { oto....... }\end{array}$ & 1.16 & 1.36 & $\begin{array}{l}\text { Transportation } \\
\text { equipment except } \\
\text { motor vehicles }\end{array}$ & 5044 \\
\hline 50931 & $\begin{array}{l}\text { Iron and steel } \\
\text { scrap }\end{array}$ & 1.21 & n.a. & Iron scraps & 5062 \\
\hline 50932 & Waste and & 1.24 & n.a. & Nonferrous & 5063 \\
\hline & $\begin{array}{l}\text { secondary } \\
\text { materials }\end{array}$ & & & scraps & \\
\hline 50993 & $\begin{array}{l}\text { Forest products } \\
\text { exc. lumber }\end{array}$ & 1.08 & n.a. & Firewood & 5193 \\
\hline
\end{tabular}


Table 2b. Estimated number of wholesale steps Japan and the U.S. by kind of wholesale business--nondurables.

\begin{tabular}{|c|c|c|c|c|c|}
\hline \multicolumn{3}{|c|}{ UNITED STATES } & \multicolumn{3}{|l|}{ JAPAN } \\
\hline sic & $\begin{array}{l}\text { kind of } \\
\text { business }\end{array}$ & NS & NS & kind of business & sic \\
\hline 51 & Nondurables & 1.49 & & & \\
\hline 511 & $\begin{array}{l}\text { Paper and paper } \\
\text { products }\end{array}$ & 1.20 & 1.47 & $\begin{array}{l}\text { Paper and paper } \\
\text { products }\end{array}$ & 5191 \\
\hline 51221 & $\begin{array}{l}\text { General line } \\
\text { drugs }\end{array}$ & 1.04 & 1.16 & Drugs & 5141 \\
\hline 51222 & $\begin{array}{l}\text { Specialty line } \\
\text { pharmaceuticals } \\
\text { ' cosmetics, } \\
\text { and toiletries }\end{array}$ & 1.19 & 1.34 & $\begin{array}{l}\text { Toiletries and } \\
\text { allied products }\end{array}$ & 5143 \\
\hline 5133 & Piece goods & 1.92 & 1.60 & $\begin{array}{l}\text { Textiles except } \\
\text { interior } \\
\text { decoration }\end{array}$ & 5014 \\
\hline 5134 & $\begin{array}{l}\text { Notions and } \\
\text { other dry goods }\end{array}$ & 1.38 & 1.50 & $\begin{array}{l}\text { Miscellaneous } \\
\text { apparel, apparel } \\
\text { accessories, and } \\
\text { notions }\end{array}$ & 5119 \\
\hline 5136 & $\begin{array}{l}\text { Men's and boys' } \\
\text { apparel }\end{array}$ & 1.12 & 1.22 & Men's clothing & 5111 \\
\hline 5137 & $\begin{array}{l}\text { Womens's, } \\
\text { children's and } \\
\text { infants' } \\
\text { apparel }\end{array}$ & 1.17 & 1.31 & $\begin{array}{l}\text { Women's and } \\
\text { children's } \\
\text { clothing }\end{array}$ & 5112 \\
\hline 5139 & Footwear & 1.31 & 1.14 & Shoes & 5115 \\
\hline 5143 & Dairy products & 1.81 & 1.67 & $\begin{array}{l}\text { Miscellaneous } \\
\text { food and } \\
\text { beverages } \\
\text { including dairy } \\
\text { products }\end{array}$ & 5139 \\
\hline $\begin{array}{l}5144 \\
5147\end{array}$ & $\begin{array}{l}\text { Poultry and } \\
\text { meat }\end{array}$ & 1.57 & 1.68 & Meat and poultry & 5125 \\
\hline 5145 & Confectionery & 1.51 & 1.45 & Bakery and & 5136 \\
\hline & & & & $\begin{array}{l}\text { Confectionery } \\
\text { products }\end{array}$ & \\
\hline 5146 & $\begin{array}{l}\text { Fish and } \\
\text { seafood }\end{array}$ & 2.27 & 2.56 & $\begin{array}{l}\text { Fresh fish, } \\
\text { shellfish and } \\
\text { seaweeds }\end{array}$ & 5126 \\
\hline
\end{tabular}




\begin{tabular}{|c|c|c|c|c|c|}
\hline \multirow{2}{*}{ UNITED } & \multicolumn{2}{|l|}{ STATES } & \multicolumn{3}{|l|}{ JAPAN } \\
\hline & $\begin{array}{l}\text { kind of } \\
\text { business }\end{array}$ & NS & NS & kind of business & sic \\
\hline 5148 & $\begin{array}{l}\text { Fresh fruits } \\
\text { and vegetables }\end{array}$ & 1.73 & 1.86 & $\begin{array}{l}\text { Vegetables and } \\
\text { fruit }\end{array}$ & $\begin{array}{l}5123 \\
5124\end{array}$ \\
\hline 51492 & $\begin{array}{l}\text { Coffee, tea and } \\
\text { spices }\end{array}$ & 1.35 & 1.67 & Tea & 5138 \\
\hline 51497 & Canned goods & 1.18 & 1.76 & $\begin{array}{l}\text { Canned and } \\
\text { bottled goods }\end{array}$ & 5135 \\
\hline 515 & Farm products & 1.42 & 1.45 & $\begin{array}{l}\text { Miscellaneous } \\
\text { farm, livestock } \\
\text { and aquatic } \\
\text { products }\end{array}$ & 5129 \\
\hline 516 & $\begin{array}{l}\text { Chemicals and } \\
\text { allied products }\end{array}$ & 1.19 & 1.45 & $\begin{array}{l}\text { Chemicals and } \\
\text { related products } \\
\text { except paints }\end{array}$ & $\begin{array}{l}502 \\
\text { exc. } \\
5021\end{array}$ \\
\hline 517 & $\begin{array}{l}\text { Petroleum and } \\
\text { petroleum } \\
\text { products }\end{array}$ & 1.74 & 1.53 & Petroleum & 5032 \\
\hline 518 & $\begin{array}{l}\text { Alcoholic } \\
\text { beverages }\end{array}$ & 1.24 & 1.36 & $\begin{array}{l}\text { Beer, wine and } \\
\text { liquors }\end{array}$ & 5133 \\
\hline 5191 & Farm supplies & 1.47 & n.a. & $\begin{array}{l}\text { Fertilizers and } \\
\text { feeds }\end{array}$ & 5194 \\
\hline 5194 & $\begin{array}{l}\text { Tobacco and } \\
\text { tobacco } \\
\text { products }\end{array}$ & 1.10 & n.a. & Tobacco products & 5196 \\
\hline 5198 & $\begin{array}{l}\text { Paints, } \\
\text { varnishes, and } \\
\text { supplies }\end{array}$ & 1.19 & 1.37 & $\begin{array}{l}\text { Paints and } \\
\text { related products }\end{array}$ & 5021 \\
\hline
\end{tabular}


Table 3. OLS regression estimates. Dependent variable = estimated number of wholesale steps by kind of business, Japan, 1986.

\begin{tabular}{|c|c|c|c|c|c|}
\hline \multirow[t]{2}{*}{ Variable } & \multirow{2}{*}{$\begin{array}{l}\text { Mean } \\
(s . d .)\end{array}$} & \multicolumn{4}{|c|}{ Coefficient estimates and t-statistics } \\
\hline & & $\begin{array}{l}(1) \\
\text { Consumer } \\
\text { products }\end{array}$ & only & $\begin{array}{l}\text { (2) } \\
\text { industrial } \\
\text { products } \\
\text { only }\end{array}$ & $\begin{array}{l}(3) \\
\text { all } \\
\text { products }\end{array}$ \\
\hline Constant & -- & $\begin{array}{c}0.456 \\
(1.838)\end{array}$ & $\begin{array}{c}0.285 \\
(1.221)\end{array}$ & $\begin{array}{c}1.351 \\
(2.837)\end{array}$ & $\begin{array}{c}1.006 \\
(5.941)\end{array}$ \\
\hline $\begin{array}{l}\text { Number of } \\
\text { wholesale } \\
\text { steps in the } \\
\text { US }\end{array}$ & $\begin{array}{c}1.36 \\
(0.28)\end{array}$ & $\begin{array}{c}0.645 \\
(4.535)\end{array}$ & $\begin{array}{c}0.589 \\
(4.109)\end{array}$ & $\begin{array}{c}0.303 \\
(0.887)\end{array}$ & $\begin{array}{c}0.498 \\
(4.276)\end{array}$ \\
\hline $\begin{array}{l}\text { Stores per } \\
\text { household in } \\
\text { Japan } \\
\text { divided by } \\
\text { stores per } \\
\text { household in } \\
\text { the Us }\end{array}$ & $\begin{array}{c}3.74 \\
(1.54)\end{array}$ & $\begin{array}{c}0.064 \\
(1.983)\end{array}$ & $\begin{array}{c}0.093 \\
(3.268)\end{array}$ & --- & --- \\
\hline $\begin{array}{l}\text { Fraction of } \\
\text { wholesalers } \\
\text { reporting } \\
\text { assistance } \\
\text { or direction } \\
\text { by upstream } \\
\text { firms }\end{array}$ & $\begin{array}{c}0.25 \\
(0.12)\end{array}$ & $\begin{array}{l}-0.563 \\
(1.628)\end{array}$ & $\begin{array}{l}-0.536 \\
(1.350)\end{array}$ & $\begin{array}{l}-0.967 \\
(1.486)\end{array}$ & $\begin{array}{l}-0.814 \\
(3.025)\end{array}$ \\
\hline $\mathrm{R}^{2}$ & --- & 0.621 & 0.571 & 0.228 & 0.405 \\
\hline $\begin{array}{l}\text { number of } \\
\text { observations }\end{array}$ & --- & 24 & 24 & 15 & 40 \\
\hline
\end{tabular}

